\title{
Jennifer Todd, Identity Change after Conflict: Ethnicity, Boundaries and Belonging in the Two Irelands
}

\section{Cillian McBride}

\section{(2) OpenEdition}

1 Journals

\section{Édition électronique}

URL : https://journals.openedition.org/etudesirlandaises/10446

DOI : 10.4000/etudesirlandaises. 10446

ISSN : 2259-8863

\section{Éditeur}

Presses universitaires de Caen

\section{Édition imprimée}

Date de publication : 31 décembre 2020

Pagination : 217-219

ISBN : 978-2-84133-996-9

ISSN : 0183-973X

\section{Référence électronique}

Cillian McBride, "Jennifer Todd, Identity Change after Conflict: Ethnicity, Boundaries and Belonging in the Two Irelands », Études irlandaises [En ligne], 45-2 | 2020, mis en ligne le 31 décembre 2020, consulté le 21 novembre 2022. URL : http://journals.openedition.org/etudesirlandaises/10446 ; DOI : https:// doi.org/10.4000/etudesirlandaises. 10446

\section{(c) (i) (2) (2)}

Creative Commons - Attribution - Pas d'Utilisation Commerciale - Partage dans les Mêmes Conditions 4.0 International - CC BY-NC-SA 4.0

https://creativecommons.org/licenses/by-nc-sa/4.0/ 
in the final chapter. Johnson shows that Irish servant migration to the Caribbean in the $17^{\text {th }}$ century, when transformed into an Irish slavery Internet meme, can become a "weaponized narrative" to obtain political advantage and claim cultural superiority over Afro-Americans.

This reminds us that popular culture has a political dimension, and that viral Internet memes can be vectors of influence, and therefore power. During this period of a global Covid-19 pandemic, it is worth considering how a real virus can also be a vector for cultural elements associated with national or racial cultural stereotypes... and conversely, how the virus may be helping to debunk some myths associated with national stereotypes.

How Popular Culture Travels is a highly stimulating and very enjoyable read, and it is to be hoped that it will encourage others to engage with this fascinating field of research.

Frank HeALY

\section{Jennifer Todd, Identity Change after Conflict: Ethnicity, Boundaries and Belonging in the Two Irelands, Basingstoke, Palgrave Macmillan, 2018, xvii +279 p.}

Ireland, North and South, has undergone significant social and political change in recent decades. Jennifer Todd seeks to understand the impact of these changes on collective identities and, specifically, how individuals have responded to these challenges. Todd, perhaps surprisingly, notes that her Northern respondents reported significantly higher levels of identity innovation than her Southern respondents (p. 3).

This provides the primary focus of the book: the attempt to understand how ordinary people manage identity change. Todd argues that the extent to which this is possible is often obscured by the assumption that "ethnicity" is especially resistant to change and that ethnic identities must be accommodated rather than transformed (p. 22). This has direct implications for how we view political institutions and informal norms demanding "recognition" for ethnic identities.

With admirable conceptual sophistication, Todd argues that such identities are usually complex composites: identity change cannot be reduced to a switch between simple identities. Rather, we should see identity change as a complex process of "reflexive distanciation" (p. 31) in which individuals both reinterpret and reposition themselves with respect to different aspects of their identities. One can remain a Protestant, for example, while opting to "do" Protestant differently (p. 31).

Todd's sharp eye for complexity is reflected in the inclusion of the story of "Ellie", brought up in a loyalist area, who moved away so that her children could grow up in a mixed environment and escape the influence of "bitterness". Despite 
endorsing innovation, "Ellie" still feels a measure of nostalgia for a past in which one could still unselfconsciously sing loyalist songs (p. 139). This also underlines another of Todd's key themes: not only is identity change possible, it is also fragile and potentially reversible.

The book is distinguished not only by its extensive empirical research, but also by its analytical approach to the material. This has three aspects. Firstly, there are three dimensions of change to group boundaries: permeability, salience, and totalization (p. 52). The first refers to rates of cross-boundary friendships and marriages. The second, salience, to the choice of which identity contrast to emphasize. The third, totalization, refers to the extent to which different identities, national, religious, class, etc. are mapped into one another creating composite social identities. Secondly, Todd distinguishes three different clusters of people: "changers", committed to subverting boundaries, "die-hards" who resist change, and "swayers" who are open to movement (p. 108).

Thirdly, Todd identifies three broad strategies individuals can adopt: privatization, pluralization, and transformation. "Privatizers" withdraw from communal identities and opt instead to make role identities (family, professional, etc.) more central to their personal identities (p. 126). Privatization may be more limited than public disavowals suggest. Pluralizers do not surrender their communal identities but opt to see the alternative identity simply as other, rather than as a threat. As one respondent puts it, "it's not that I'm... anti-them, it's just that I'm not them" (p. 130). While both Protestants and Catholics adopt this strategy, Todd notes that, in her sample, Catholics were especially strongly represented. Pluralization can be more difficult for Protestants to the extent that their identities are state-centred (p. 136). Efforts to rebalance institutions can be perceived as attacks on group identity. Finally, there are "transformers", who make a more thoroughgoing effort to broaden one's perspective and reflect on and reinterpret one's social identities in order to divest themselves of "sectarian baggage" (p. 133).

The greater prevalence of identity change in the North is explained by Todd as a product of "normative dissonance": the sense that group norms and narratives no longer mesh well with personal experiences (p. 111). In general, Todd finds that "groupness" (p. 21) is widely thought to be a contingent fact to be reckoned with rather than as something desirable as such. Respondents were also highly reflexive and understood group identities as interlocking composites, rather than as simple blocs. Perhaps the central theme of the analysis, however, is that innovation while both possible and common is also reversible. This, she argues, is especially true of pluralizers, who can easily find themselves reverting to more conflictual relations when circumstances change. As evidence, Todd points to the availability of "disappointed pluralizers" (p. 208) for loyalist mobilization during the Flag protests in 2012-2013. An additional complication is that some can find themselves in "identity traps": those who are motivated to innovate with respect to their identities but find themselves without the resources to do so (p. 191).

This analysis poses a serious challenge to the long-term viability of pluralism as a strategy. If we are to encourage more stable forms of identity innovation more 
attention must be paid to providing the resources with which to escape identity traps. Todd argues that we must move away from the idea that we must "respect" given identities and embrace respect for autonomous identity change (p. 220). While this is often dismissed on the grounds that it represents a failure to appreciate the importance and persistence of communal identities, Todd makes a very persuasive case for viewing the assumption that "ethnic" identities are immoveable as an oversimplification. In this rich and compelling analysis Todd shows that identity changes are possible even in challenging circumstances even if they are, at the same time, far from certain or easy.

Cillian McBRIDE 